Revue Française de Civilisation Britannique

\title{
Northern Ireland: Devolution as an Electoral Issue in the 2015 UK General Election
}

L'Irlande du Nord: la dévolution en tant qu'enjeu électoral lors des élections

législatives de 2015

\section{Valérie Peyronel}

\section{OpenEdition}

\section{Journals}

Electronic version

URL: http://journals.openedition.org/rfcb/647

DOI: $10.4000 / \mathrm{rfcb} .647$

ISSN: 2429-4373

Publisher

CRECIB - Centre de recherche et d'études en civilisation britannique

Electronic reference

Valérie Peyronel, « Northern Ireland: Devolution as an Electoral Issue in the 2015 UK General Election », Revue Française de Civilisation Britannique [Online], XX-3 | 2015, Online since 01 December 2015, connection on 30 April 2019. URL : http://journals.openedition.org/rfcb/647 ; DOI : 10.4000/rfcb.647

This text was automatically generated on 30 April 2019.

\section{$\oplus \Theta \Theta \Theta$}

Revue française de civilisation britannique est mis à disposition selon les termes de la licence Creative Commons Attribution - Pas d'Utilisation Commerciale - Pas de Modification 4.0 International. 


\title{
Northern Ireland: Devolution as an Electoral Issue in the 2015 UK General Election
}

\author{
L'Irlande du Nord: la dévolution en tant qu'enjeu électoral lors des élections \\ législatives de 2015
}

Valérie Peyronel

By comparison with its counterparts, Scotland and Wales, devolution in Northern Ireland is very particular. After 26 years of Direct Rule from 1972 to 1998 , the Agreement ${ }^{1}$ (usually better known as the Good Friday Agreement) was signed on April 10, 1998 after nearly a decade of harsh negotiations including representatives of the unionist and nationalist parties in Northern Ireland ${ }^{2}$ as well as representatives of the British and Irish governments ${ }^{3}$ and external mediators. ${ }^{4}$ It provided Northern Ireland with a new opportunity to make devolution work on the basis of a shared Northern Ireland Executive and a shared Assembly at Stormont, thus guaranteeing both communities and their political representatives equal representation in political debates.

Operating devolution in this so-called post-conflict context has been difficult, complex, and the deal was broken several times, ${ }^{5}$ causing the temporary suspension of the Northern Ireland institutions and compelling Downing Street and Westminster to take over, as in the old troubled times. However, both the Northern Ireland Executive and Stormont have now been functioning for eight years in a row, and a lot has been achieved over the last 17 years, notably in terms of police and justice reform, ${ }^{6}$ urban renovation ${ }^{7}$ and community relations, ${ }^{8}$ north-south economic relations, ${ }^{9}$ as well as economic modernisation (in particular attracting Foreign Direct Investment in innovative hightechnology sectors). ${ }^{10}$

But the situation still remains complicated and contentious. Indeed devolution in Northern Ireland has to do with much more than simply entrusting local representatives with the power to decide on local matters, and the duty to develop a locally sustainable political, social, economic and cultural system. In Northern Ireland, devolution requests 
the stakeholders, as well as the citizens, to abide by the very condition of showing their capacity to live and work peacefully together, despite vitally different political aspirations: remaining in the UK for the unionists, reuniting Ireland for the most extreme nationalists. The 1998 Agreement states that the decision on whether Northern Ireland should remain British or become Irish again lies in the people of Northern Ireland's hands: "The participants [...] recognize the legitimacy of whatever choice is freely exercised by a majority of the people of Northern Ireland with regard to its status, whether they prefer to continue to support the Union with Great Britain or a sovereign united Ireland." 11 So far, no referendum has been organised on this very hot issue, but the sword is hanging above Northern Ireland's political future.

\section{The Stormont House Agreement: Setting the Context of the General Election Campaign}

In the 2011-2015 period separating the two general election campaigns, the citizens of Northern Ireland's capacity to work together and smoothly operate devolution was put to the hard test. First of all, the context of very slow economic recovery characterising the aftermath of the 2007 financial crisis was very stressful, although, to some extent, the recovery has been more marked in NI than in other parts of the UK. Acute disagreements occurred on several issues, prompting David Cameron as well as his counterpart, Enda Kenny, the President of the Republic of Ireland, to support Teresa Villiers, the Secretary of State for Northern Ireland, in her attempt to bring multi-party negotiations in NI to a favourable conclusion. In an interview on October 7, 2014, David Cameron disclaimed accusations of being "detached" regarding Northern Ireland: "The point of devolution is for the devolved institutions to deliver for the people of Northern Ireland", requiring "people working together to make compromises". ${ }^{12}$

The bones of contention between the opposed parties referred to finance and welfare, to institutional reform, to identity and cultural issues (among which flags and emblems), and finally to dealing with the past and with victims.

Obviously, the multifaceted scope of the disagreements (along the usual unionist/ nationalist divide) reflected the intricacy of the devolution process in Northern Ireland, where matters of cultural traditions and cultural conflict interfere with or matter just as much as (if not more than) more general and national stakes such as nationwide economic and welfare policies. But with the forthcoming general election in sight, it was David Cameron's interest not to stumble on a failed Northern Ireland devolution process, and for the Northern Ireland party leaders to secure votes by defending their respective voters' interests on the above-mentioned issues.

The Stormont House Agreement, which was signed on December 23, 2014, four days after the official start of the General election campaign, tackled the four issues. Interestingly, the Agreement document starts with the "Finance and Welfare" issue, then "Flags, identity, culture and tradition", followed by "The past". "Institutional reform" comes last. More importantly, devolution and community relations issues are intertwined in each of these four chapters.

In the "Finance and welfare" chapter, the financial and economic arrangements of the Agreement definitely point to more devolution. The Agreement advocates local responsibility for a balanced budget and a reform of public services to improve quality 
and reduce administrative costs, but also, to compensate this austerity package, It also recommends the development of flexibilities and top-ups from the block grant to better address local needs. It underlines the need for the devolution of corporation tax as from April 2017, and possibly some additional fiscal devolution for Northern Ireland including aggregates Levy, Stamp Duty, Land Tax and Landfill Tax.

But beside tackling the budgetary and economic aspects, the text also mentions the appointment of an independent audit of departmental spending in charge of identifying how divisions in society impact the delivery of goods, facilities and services, and of considering how best to reconfigure service delivery in a manner consistent with a shared discrimination-free future.

As far as "Flags, identity, culture and tradition" are concerned, the Agreement states that the power to take responsibility for parades and related protests should, in principle, be devolved to the NI Assembly. But it also plans the establishment of a Commission by June 2015 seeking to identify maximum consensus on their application of decisions regarding flags and emblems as well as broader issues of identity, culture and tradition.

To deal with "The past", which is the third issue at stake, the Agreement guarantees local empowerment thanks to the creation of an Oral History Archive by 2016 and the creation of a Historical Investigations Unit (HIU) "to take forward investigations into outstanding Troubles-related deaths". ${ }^{13}$ The involvement of the UK Government is made clear by its explicit commitment to full disclosure to the HIU. Finally, in order to better deal with victims and survivors an Independent Commission on Information Retrieval (ICIR) is to be appointed by both the British and Irish Governments.

Finally the chapter on Institutional Reform provides for reforms to improve the operation of devolution in Northern Ireland: reducing the number of Assembly members (5 per constituency) by 2021; organising arrangements by March 2015 to enable "those parties which would be entitled to ministerial positions in the Executive, but choose not to take them up, to be recognised as an official opposition and measures to facilitate their work"; ${ }^{14}$ drawing up a range of other provisions to "promote greater efficiency in the conduct and discharge of Executive business", 15

Furthermore, the Agreement even states that

The UK Government also stands ready to consider potential further areas of devolution and changes to intergovernmental machinery which are under discussion elsewhere in the UK and likely to command broad support among parties in Northern Ireland. ${ }^{16}$

But the conditions under which these reforms can be implemented are clearly stated, and all the parties must commit to keeping the post-conflict process up and alive. Indeed, Article 69 in the Stormont House Agreement states that as no consensus has yet been reached by the parties on a Bill of Rights, the latter have to commit to fostering a proper context for a successful shared society:

serving the people of Northern Ireland equally and to act in accordance with the obligations on government to promote equality and respect and to prevent discrimination; to promote a culture of tolerance, mutual respect and mutual understanding at every level of society, including initiatives to facilitate and encourage shared and integrated education and housing, social inclusion, and in particular community development and the advancement of women in public life; and to promote the interests of the whole community towards the goals of reconciliation and economic renewal. ${ }^{17}$ 
Furthermore article 72 lays an obligation upon the shared Northern Ireland Executive to "commit to a continuing effort to eradicate sectarianism in all forms"18 and the reviewing process includes the Northern Ireland Executive party leaders as well as the UK and Irish governments (article 72) reflecting the three-stand approach.

Martin Mc Guinness, of Sinn Féin, and Northern Ireland's current Deputy First Minister said that the deal could give the Northern Ireland Executive a "fresh start", qualifying this optimistic statement by admitting that it was yet incomplete: "Of course every one of us would have liked to have had a more comprehensive and complete agreement but this is as much and more than we have ever been able to do on these issues in the past." ${ }^{19}$ DUP leader Peter Robinson, the current First Minister of Northern Ireland, also declared that the deal was an achievement. However, the SDLP, who finally did sign the agreement, did so reluctantly after having warned that "the outcome [was] not comprehensive or decisive across all issues". ${ }^{20}$ Alliance leader, David Ford, declared that the Agreement "fell short" ${ }^{21}$ of expectations and the UUP expressed that the proposals included "many aspects of uncertainty". ${ }^{22}$

\section{Electoral Stakes in Northern Ireland}

Such was the devolution context in which the 2015 Westminster electoral campaign started: devolution indeed, but devolution under the tight control of the British government and the Conservative current political agenda; an austerity package and budget control as a pre-requisite to the devolution of corporation tax (and possibly even more fiscal devolution in the longer term); the obligation to keep dealing with community relations and post-conflict issues as a cornerstone and continuous prerequisite for devolution and, finally, what sounded like an unusually more consensual political climate in Northern Ireland.

But beyond the apparent consensus, there was a general election to be run and the question was for the parties to orchestrate their campaign so as to simultaneously gather the support of their voters for the Westminster election and make Northern Ireland's voice heard next to Wales and Scotland while paving the way for the forthcoming local elections due to take place in Northern Ireland in 2016.

In an article published on April 1, 2015, a little more than one month before the election, Professor John D. Brewer, a specialist of post-conflict politics at Queen's University in Belfast, underlined the "parochialism" of the political debates in Northern Ireland, even in the frame of a general election:

The issues that will dominate political discourse in Britain in the coming weeks will be largely absent in Northern Ireland. There will be silence over Europe and the referendum. Immigration will hardly feature, nor even will austerity, or cheating on tax or benefits. The legacy issues from Northern Ireland's conflict will dominate as a surrogate for political contestation over the morality of the war, the morality of the settlement, and the morality of dealing with the past..$^{23}$

Indeed in Northern Ireland, local and general elections are closely related, in so far as the scores reached by each of the communities' political representatives in any election (local, national or even European) is a contribution to the inner fight for power within Northern Ireland, even in spite of the devolved power-sharing structure which is meant to guarantee equal representation of the unionist and the nationalist sides. John Brewster describes a continuous process of "sectarian politics" which the terms of the 1998 
Agreement have not infringed (or very little so). Of course, sectarianism is particularly vividly expressed in the occasion of local elections, as the stakes are more directly related to locally contentious issues and every seat in the power-sharing assembly must be won so as to win over the other community:

The main electoral battles are not between the two main governing parties, Sinn Féin (SF) on the Nationalist side and the Democratic Unionist Party (DUP) on the Unionist side. In devolved elections, they compete to become the single largest party, thereby winning the right to choose the First Minister; Rather than being between the two parties, the outcome is determined by their ability to win the sectarian vote within their "tribe". ${ }^{24}$

But considering the very small number of seats for the Northern Ireland MPs in Westminster, ${ }^{25}$ the general election and, even more so, the European elections, are a smaller incentive to cut-throat competition for votes among the parties in Northern Ireland. Whatever their position, Northern Ireland's representatives' voices cannot make a difference in the national debate, unless they partner up with representatives of the major parties. One piece of evidence of the little influence Northern Ireland MPs may have on Westminster debates is the fact that Sinn Féin, usually a very fiery party, does not even take its seats in Westminster. Officially their attitude is dictated by their symbolic refusal to take seats in a British Parliament. But should there be any means for them to have the final say in the debates their position might be quite different

In the 2015 general election campaign, however, there were two motives for a stronger interest by the parties of Northern Ireland. Indeed, when a general election takes place little before the local elections, as was the case with the forthcoming local elections due to take place in 2016, it serves as a test for each party's potential and for their electoral support. As John Brewster put it: "What matters in the race is primarily prestige within the landscape of the identity politics back home."26 Another important incentive to win seats in Westminster this time was the perspective of a possibly hung Parliament with neither of the two main parties, Labour or the Conservatives, being able to win a majority. The interest of the larger parties in Northern Ireland (like their counterparts' in Scotland and Wales) was spurred by the possibility of being offered an unusual opportunity to have more influence in Westminster, to voice their concerns about any matter regarding Northern Ireland, directly or indirectly.

\section{Devolution and the UK in the Manifestos}

How were the issues that had been addressed in the Stormont House Agreement to make the devolution "work better" used and debated during the General Election campaign? And to what extent were local and national concerns intertwined? In spite of the consensus reached in the Stormont House Agreement, the basic line of the unionist/ nationalist divide did not shift during the campaign and the general election campaign also very much staged local concerns.

As for the institutional framework, on the unionist side, the UUP and the DUP manifestos took a very clear stand in favour of devolution and the necessary unity of the Kingdom. The UUP campaign was particularly pro devolution and pro UK: "A stable Union is the most important result a good unionist should hope for in his Election.... While our MPs will seek to do the best they can for the people of NI, we will also work in the best interests of the UK as a whole." ${ }^{27}$ 
But the DUP, while not questioning the devolution, expressed firmer views on the responsibilities of Westminster, expected, on the one hand, to guarantee the institutional framework necessary for the smooth functioning of the devolved power-sharing structure in Northern Ireland, and, on the other hand, to remain supportive: " For us to deliver the kind of changes and improvements that we want to see, we will need the support of Westminster to make sure that politics operates better in Northern Ireland. This includes a guaranteed seat in the Cabinet and an agreed minimum level of representation for Northern Ireland in the House of Commons." 28

At the other end of the political spectrum, Republican Sinn Féin, while having supported the Stormont House Agreement and praised this new chance given to devolution in Northern Ireland, reaffirmed in their general election manifesto "the right to a Referendum on Irish unity [as] one of several outstanding issues within the Good Friday Agreement and other agreements which the British Government [needed] to act upon", even "[calling] for the Irish Government to plan for Irish unity". ${ }^{29}$ Obviously, as the only party in Northern Ireland, in the UK and in the Republic of Ireland holding a North-South national Irish position, Sinn Féin's stand is very singular, and its participation both in the local elections in Northern Ireland and in the British election is also meant to enlarge its electoral basis as an allparty Ireland. So while firmly participating in the positive outcome of the Stormont House Agreement so as not to be side-lined in the power-sharing dynamics in Northern Ireland, Sinn Féin also had to make their nationalist position very clear in their manifesto.

The SDLP's position was more ambiguous, as the party supported more devolution to Northern Ireland (among other fields in broadcasting, national insurance and minimum wage, energy and mineral resources), but as a means to pave the way for a united Ireland, advocated as a final outcome by a party who, although not as radically positioned as Sinn Féin, would not betray its nationalist obedience: "In a united Ireland, we see the continuation of a Stormont Assembly and we see the same rights and protections that the SDLP delivered as part of the GFA". ${ }^{30}$

The Alliance Party, quoting the Scottish referendum experience, and faithful to its median position, advocated a "move towards a federal UK", with "additional powers conferred on the devolved administrations." 31

As far as economic and welfare issues are concerned, all parties presented the economic recovery and development of Northern Ireland, with a strong emphasis on the development of the private sector, as an absolute priority, and in line with the Stormont House Agreement, they all pleaded for fiscal devolution.

The UUP manifesto was very precise, claiming that the devolution of corporation tax was an essential means to make Northern Ireland less dependent on the block grant, insisting that Northern Ireland had "paid [its] way" when Northern Ireland was a "major economic powerhouse", and that it was time, after years of dependency on British subsidies, to "shift from dependency to wealth generation". ${ }^{32}$ In particular, the devolution of corporation tax would enable Northern Ireland to compete against the record 12.5\% Foreign Direct Investment attractive corporation tax rate in the Republic and would "represent a $7.5 \%$ positive differential with Great Britain". ${ }^{33}$ While nationalist Sinn Féin also shed the light on the comparison between the Republic and Northern Ireland, the focus was laid on the potential reunification of the island with a usual Sinn Féin national all-island scope: "The potential of our island economy is strong. Harmonising tax regimes [...] is central to creating a fully 
integrated and healthy economy [...] and creating a better business climate for advancement of entrepreneurial spirit north and south." ${ }^{34}$

The DUP's and the SDLP's approaches on tax issues were broader, the unionist DUP advocating a "UK wide tax policy improvements to encourage economic growth in Northern Ireland" ${ }^{35}$ while the nationalist SDLP pleaded for more fiscal independence to generate more wealth: "A Scottish-style commission to begin the devolution of further powers which will allow us to take control of additional fiscal levers". ${ }^{36}$ The Alliance Party manifesto, while advocating more fiscal transparency and fairness and a better administration of tax, was silent on the issue of the devolution of corporation tax, thus not opposing it.

But tax devolution is just as far as the consensus went in the manifestos. Indeed, divergences clearly appeared on economic and welfare issues during the campaign. However, quite interestingly, the traditional unionist/nationalist divide was superseded by what sounded more like a right wing/left wing one, the parties taking different stands on the British Government's austerity programme and its impact on devolved Northern Ireland. The UUP somewhat stood out, advocating very liberal economic strategies, supporting cost-saving reforms in the public sector and encouraging the development of the private sector as a means to boost long-term economic recovery: "switching from a culture of Dependency on welfare and the Block Grant to a mind-set where we are focused on generating serious wealth for all our people" to bridge the huge prosperity gap between Northern Ireland and the rest of the UK". ${ }^{37}$

While the DUP also supported the idea of "sustained growth in the private sector", ${ }^{38}$ it joined Sinn Féin and the SDLP in opposing any further budget cuts and a reform of the public services that would be detrimental to the people of Northern Ireland. The title of Sinn Féin's manifesto was unequivocal in this regard: "Equality not Austerity", as was the SDLP's: "Prosperity, not Austerity".

The third major theme tackled in the Stormont House Agreement, "Dealing with postconflict issues" was more consensual during the electoral campaign. In line with the Stormont House Agreement, three parties made convergent proposals (although not completely similar) to address post conflict issues, as part of the implementation of the Good Friday Agreement and of the devolution process: "Building a society that welcomes diversity" ${ }^{39}$ in the UUP's manifesto, "uniting communities and tackling sectarianism" ${ }^{40}$ in Sinn Féin's, "continuing sustained lobbying for a strong Bill of Rights" 41 in the SDLP's. The Alliance party was most explicit about the role played by local institutions in building a more peaceful society in Northern Ireland: "Most of the mechanisms for delivering a shared future for Northern Ireland such as the powers to integrate education and build shared communities are devolved to the Northern Ireland Assembly. However Westminster has an important role to play in ensuring that a shared future and good relations are central to Northern Ireland's work." ${ }^{4}$

In contrast, though, the stand taken by the unionist DUP in its manifesto was very minimal. In the manifesto introduction, Peter Robinson wrote "We want to create a shared and united Northern Ireland"43 but the remaining part of the sentence presented this unity as a prerequisite for economic prosperity and not as a full-fledge objective. Chapter 4 of the manifesto, entitled "Traditions and identity", proposed various programmes meant to reinforce the cohesion between Northern Ireland and other parts of the UK, but there was no mention at all of any means to settle intercommunity disputes or reinforce cohesion within Northern Ireland. 


\section{The General election Results in Northern Ireland}

The results of the election confirmed the predominance of unionist vote in Northern Ireland, both in terms of vote share and in terms of seats.

\begin{tabular}{|l|l|l|l|l|}
\hline \multicolumn{2}{|l|}{2010} & \multicolumn{2}{l|}{2015} \\
\hline Parties & Seats & Vote share & Seats & Vote share \\
\hline DUP & 8 & $25 \%$ & 8 & $25.7 \%$ \\
\hline UUP & 0 & $15.2 \%$ & 2 & $16 \%$ \\
\hline Sinn Féin & 5 & $25.5 \%$ & 4 & $24.5 \%$ \\
\hline SDLP & 2 & $16.5 \%$ & 2 & $13.9 \%$ \\
\hline Alliance & 1 & $6.3 \%$ & 0 & $8.6 \%$ \\
\hline
\end{tabular}

Source: table adapted by the author from The Electoral Commission UK, http:// www.electoralcommission.org.uk/find-information-by-subject/elections-and-referendums/pastelections-and-referendums/uk-general-elections, accessed June 9, 2015.

With a total of $41.7 \%$ of vote share and 10 seats, the unionists took the lead over the nationalists with only $38.4 \%$ of vote share and 6 seats. Compared with 2010, the unionists won $1.7 \%$ in the vote share but the first-past-the-post system enabled them to win two seats, while the nationalists lost $3.6 \%$ in vote share and lost one seat. The unionists managed to win one seat from nationalist Sinn Féin and one from the moderate Alliance Party. This success was the result of a coalition campaign between the DUP and the UUP, spurred by the common defence of the Union, as well as, on the one hand, by the perspective of a better representation of unionist Ireland in a no-majority Westminster and, on the other hand, by the failure, for the UUP, of the 2010 UUP-Labour alliance. As unionist politician Simon Hamilton declared: "I think the big message coming out of this election is that it's a great result for unionism". ${ }^{44}$

Analysts also explain Sinn Féin's declining vote share by the fact that the party's campaign was very much based on putting an end to austerity, while, as one of the two major parties operating the Northern Ireland shared Executive and Stormont, they had been part of the implementation of the austerity package imposed by the British Government and by Westminster. According to analyst Jordan Shilton, Sinn Féin's “ posture as a left alternative to the austerity measures that have been implemented throughout Britain since 2008, including in Northern Ireland, is increasingly being discredited". ${ }^{4}$

But the major loser in the 2015 general election in Northern Ireland, as both the result of the DUP-UUP coalition and the first-past-the-post system, was the Alliance Party: despite the fact that they scored better in vote share in 2015 than they had done in 2010 (8.6\% in 2015 compared with $6.3 \%$ in 2010), they lost their only seat ${ }^{46}$ in Westminster. However, the fact that their vote share was the highest since 1992 is evidence that among their traditionally more moderate middle-class electorate, Alliance keep gaining momentum 
and the forthcoming 2016 elections might tell a slightly different story from the 2015 General election one.

\section{Conclusion}

In spite of a more favourable and apparently more consensual political context fostered by the recently signed Stormont House Agreement, the 2015 General election campaign in Northern Ireland once again illustrated the divergences between the parties regarding a large range of issues relating to the functioning of the devolved institutions. The basic unionist/nationalist divide, however, was blurred on some issues to the benefit of a more traditional liberalism vs welfare debate. However, devolution as such has not been questioned, and the unionist victory has made no difference in that regard. Some issues like the devolution of corporation tax have even gathered the support of all the parties involved. However, with the forthcoming 2016 local elections in sight, it will be interesting to observe, on the one hand, how the five major parties capitalise on the 2015 General election results (and, in particular, what the Alliance party's results will be) and, on the other hand, whether, in the meantime, the Northern Ireland shared Executive will manage to implement the Stormont House Agreement which is meant to support a better and more consensual devolution system in Northern Ireland.

\section{BIBLIOGRAPHY}

ALLIANCE, Step forward, not back, Manifesto for 2015 Westminster Election, 32 p.

BBC, "Northern Ireland talks. Broad Agreement is brokered on some key issues", BBC News, December 23, 2014, http://www.bbc.com/news/uk-northern-ireland-30589804

BBC, “Alliance Party ratifies Northern Ireland Agreement”, BBC News online, January 8, 2015, http://www.bbc.com/news/uk-northern-ireland-30737797

BBC, “Election 2015: Sinn Féin loses Fermanagh and South Tyrone", May 8, 2015, http:// www.bbc.com/news/election-2015-northern-ireland-32629703

BREWSTER, John, D., "Post conflict elections in Northern Ireland", April 1, 2015, Discover society, http://discoversociety.org/2015/04/01/post-conflict-elections-in-northern-ireland/

DEMOCRATIC UNIONIST PARTY, DUP Westminster Manifesto 2015, 31 p.

McCANN, David; “SDLP not to ratify Stormont House Agreement”, Slugger O'toole online, January 10, 2015, http://sluggerotoole.com/2015/01/10/sdlp-not-to-ratify-stormont-house-agreement/

McHUGH, Michael, “Ulster Unionist Party warns over Stormont House Agreement 'uncertainty' “, Belfast Telegraph, January 5, 2015.

SHILTON, Jordan, "Sinn Fein loses ground in UK elections in Northern Ireland, World socialist website, May 13, 2015, https://www.wsws.org/en/articles/2015/05/13/nire-m13.html

SINN FEIN, Equality not Austerity, 2015 Westminster Election Manifesto, 15 p. 
SOCIAL DEMOCRATIC AND LABOUR PARTY, Prosperity not Austerity, Westminster manifesto 2015, $24 \mathrm{p}$.

UK GOVERNMENT, The Agreement, April 10, 1998, https://www.gov.uk/government/ publications/the-belfast-agreement

UK GOVERNMENT, Stormont House Agreement, December 23, 2014, https://www.gov.uk/ government/publications/the-stormont-house-agreement,

ULSTER UNIONIST PARTY, Ulster Unionist Party manifesto, One Chance for Change, Westminster Manifesto 2015, 24 p.

WALKER, Stephen, “ David Cameron says he hopes Northern Ireland Executive will not collapse”, BBC News online, October 7, 2014, http://www.bbc.com/news/uk-northern-ireland-

politics-29525766

\section{NOTES}

1. UK government, The Agreement, https://www.gov.uk/government/publications/the-belfastagreement, 10 April 1998.

2. There are four main parties in Northern Ireland. On the unionist side, the Democratic Unionist Party (DUP) is the largest one. It was founded in 1971 by Reverend Ian Paisley and has traditionally been supportive of a strong loyalism to Britain. The Ulster Unionist Party (UUP) governed Northern Ireland from 1921 to 1972 and the return to direct rule ? as a result of the Troubles in Northern Ireland. Since the creation of the DUP, it has lost ground as a more moderate unionist party. On the nationalist side, the major party is Sinn Féin (which means "Ourselves alone"), which is represented both in Northern Ireland and in the Republic of Ireland. The original party was founded in 1905, under the Union, by Arthur Griffith, but the current party was created after a split in 1970. Sinn Féin is known for its association with the Irish Republican Army, despite its denials. The Social Democratic and Labour Party (SDLP) is the moderate nationalist party. It was founded in 1970 and was the major nationalist party until 1994, when it started losing ground to Sinn Féin, a few years before the signing of the 1998 Belfast Agreement which was to restore devolved powers in Northern Ireland. The fifth party is the Alliance party. It was founded in 1970 as a moderate non sectarian unionist alternative, but with time has become a median non sectarian party.

3. The Belfast Agreement was signed by British Prime Minister Tony Blair and Irish Taoiseach Bertie Ahern.

4. US President Bill Clinton and former US Senator George Mitchell were involved in the process.

5. Devolution was suspended for three months in February 2000, twice in 2001 for a day and for almost five years in October 2002. The last and very long interruption was due the refusal of UUP to share power with Sinn Féin, after it was revealed that the IRA had spied upon Stormont.

6. The police and justice have been reformed since the signing of the 1998 Belfast Agreement, so as to guarantee a more equal representation of Catholics and Protestants in the police, and a fairer and non sectarian treatment of all the citizens of Northern Ireland by the judiciary.

7. In post conflict strategies, urban renovation is considered as a means to pacify community relations by offering a common attractive physical environment facilitating contact and reciprocal understanding thinks to shared activities. Urban renovation is also necessary to attract investment and foster economic recovery.

8. Since 1998, state- or European Commission-sponsored programmes have been implemented to improve community relations. 
9. The 1998 Agreement provided for an improvement of north-south relations, in particular via the creation of a North/South Ministerial Council. Since 1998, north/south economic relations have boomed, supported by business initiatives like Intertrade Ireland.

10. ICT and electronics, Life and health sciences, Aerospace and defence.

11. The Agreement, article 1(i), p. 3.

12. Stephen WALKER, "David Cameron says he hopes Northern Ireland Executive will not collapse", BBC News online, October 7, 2014, http://www.bbc.com/news/uk-northern-irelandpolitics-29525766, accessed October 9, 2014.

13. UK GOVERNMENT, Stormont House Agreement, December 23, 2014, https://www.gov.uk/ government/publications/the-stormont-house-agreement, p. 6, accessed March 31, 2015.

14. Ibid, p. 11

15. Ibid, p. 11

16. Ibid, p. 12

17. Ibid, p. 13

18. Ibid, p. 14

19. "Northern Ireland talks. Broad Agreement is brokered on some key issues", BBC News, December 23, 2014, http://www.bbc.com/news/uk-northern-ireland-30589804, accessed January 5, 2015.

20. David MCCANN; “SDLP not to ratify Stormont House Agreement", Slugger O'Toole online, January 10, 2015, http://sluggerotoole.com/2015/01/10/sdlp-not-to-ratify-stormont-houseagreement/, accessed January 12, 2015.

21. BBC, "Alliance Party ratifies Northern Ireland Agreement", BBC News online, January 8, 2015, http://www.bbc.com/news/uk-northern-ireland-30737797, accessed January 12, 2015.

22. Michael McHUGH, "Ulster Unionist Party warns over Stormont House Agreement 'uncertainty”, Belfast Telegraph, January 5, 2015, http://www.belfasttelegraph.co.uk/news/ northern-ireland/ulster-unionist-party-warns-over-stormont-house-agreement-

uncertainty-30883469.html, accessed January 12, 2015.

23. John D. BREWSTER, "Post conflict elections in Northern Ireland", April 1, 2015, Discover society, http://discoversociety.org/2015/04/01/post-conflict-elections-in-northern-ireland/, accessed April 15, 2015.

24. Ibid.

25. 16 seats

26. Op. cit., John BREWSTER.

27. ULSTER UNIONIST PARTY, Ulster Unionist Party manifesto, One Chance for Change, Westminster Manifesto 2015, p. 4.

28. DEMOCRATIC UNIONIST PARTY, DUP Westminster manifesto 2015, p.4.

29. SINN FEIN, Equality not Austerity,2015 Westminster Election Manifesto, p. 7

30. SOCIAL DEMOCRATIC AND LABOUR PARTY, Prosperity not Austerity, Westminster manifesto 2015, p. 21.

31. ALLIANCE PARTY, Step forward, not back, Manifesto for 2015 Westminster election, p. 10.

32. ULSTER UNIONIST PARTY, One Chance for Change, op.cit., p. 11

33. Ibid.

34. SINN FEIN, Equality not austerity, op.cit., p. 11

35. DEMOCRATIC UNIONIST PARTY, DUP Westminster Manifesto 2015, p. 10

36. SOCIAL DEMOCRATIC AND LABOUR PARTY, Prosperity not Austerity, op.cit., p. 4

37. ULSTER UNIONIST PARTY, One Chance for Change, op.cit., $\mathrm{p} 11$.

38. DEMOCRATIC UNIONIST PARTY, DUP Westminster Manifesto 2015, op.cit., p. 10

39. ULSTER UNIONIST PARTY, One Chance for Change, p. 21.

40. SINN FEIN, Equality Not Austerity, op.cit. p. 4.

41. SOCIAL DEMOCRATIC AND LABOUR PARTY, Prosperity not Austerity, op.cit., p. 21. 
42. ALLIANCE PARTY, Step Forward Not Back, op.cit., p. 6.

43. Ibid, p. 4.

44. BBC, "Election 2015: Sinn Féin loses Fermanagh and South Tyrone", May 8, 2015, http:// www.bbc.com/news/election-2015-northern-ireland-32629703, accessed May 9, 2015.

45. Jordan SHILTON, "Sinn Féin loses ground in UK elections in Northern Ireland", World Socialist Website, May 13, 2015, https://www.wsws.org/en/articles/2015/05/13/nire-m13.html, accessed May 25, 2015.

46. The seat held in Westminster was East-Belfast.

\section{ABSTRACTS}

The 2015 General Election in Northern Ireland was set in the particular context of the Stormont House Agreement, which was reached on December 23, 2014, in a renewed attempt to make devolution in Northern Ireland, as defined in the 1998 "Good Friday" Agreement, operate more smoothly. On top of tackling the inescapable issues of finance and welfare in a still sluggish postfinancial crisis economic context, the Stormont House Agreement indeed addressed several dividing issues, such as flags, identity, culture and tradition, dealing with the past and institutional reform. This article analyzes the stands taken during the electoral campaign by the five main parties in Northern Ireland (the Democratic Unionist Party, the Ulster Unionist Party, the Social and Democratic and Labour Party, Sinn Féin and the Alliance Party) on the various issues raised in the Stormont House Agreement, underlining their convergences and divergences. It also briefly looks at the results and challenges ahead, in the particular context of the so called "post-conflict" Northern Ireland.

Les élections législatives de 2015 en Irlande du Nord se sont tenues peu après qu'ait été conclu, le 23 décembre 2014, l'Accord de Stormont House, une nouvelle tentative destinée à faire fonctionner la dévolution en Irlande du Nord, telle que définie par l'Accord de 1998 dit du "Vendredi Saint », de manière plus efficace. En sus des sujets de politique financière et sociale inévitables dans un contexte économique post-crise financière encore morose, l'Accord de Stormont House aborde en effet plusieurs sujets controversés comme les drapeaux, l'identité, la culture et la tradition, la gestion du passé et les réformes institutionnelles. Cet article analyse la position des cinq principaux partis d'Irlande du Nord pendant la campagne ((le Democratic Unionist Party, le Ulster Unionist Party, le Social and Democratic and Labour Party, Sinn Féin and l'Alliance Party) sur les différents thèmes inclus dans l'Accord de Stormont House, en soulignant les points de convergence et de divergence. Il examine également brièvement les résultats ainsi que les défis à venir, dans le contexte particulier de ce que l'on appelle l'Irlande du Nord de l'après-conflit.

\section{INDEX}

Keywords: Northern Ireland, devolution, general election 2015, Stormont House Agreement, post-conflict

Mots-clés: Irlande du Nord, dévolution, élections législatives 2015, Stormont House Agreement, après-conflit 
AUTHOR

VALÉRIE PEYRONEL

Université de la Sorbonne Nouvelle Paris 3 